\title{
Pembuatan Game Edukasi Tentang Penggunaan Energi Listrik Secara Bijak Berbasis Android
}

\author{
Ruri Wijaya ${ }^{a}$, Hafid Setyo Hadi, M.T ${ }^{b}$, \\ ${ }^{a}$ Politeknik Negeri Media Kreatif, Jakarta \\ ${ }^{b}$ Politeknik Negeri Media Kreatif, Jakarta
}

\section{INFORMASI ARTIKEL}

Sejarah Artikel:

Diterima Redaksi: 28 Mei 2020

Revisi Akhir: 15 Juli 2020

Diterbitkan Online: 31 Juli 2020

\section{KATA KUNCI \\ Energi Listrik, Secara Bijak, Game Edukasi. \\ KORESPONDENSI}

Email Mahasiswa : rury.wijaya@gmail.com

E-mail Dosen: hafid@polimedia.ac.id

\section{A B $\mathbf{S}$ T $\mathbf{R}$ A $\mathbf{C}$ T}

Energi Listrik merupakan salah satu kebutuhan pokok yang sangat penting dalam kehidupan manusia saat ini, karena hampir setiap kegiatan yang dilakukan masyarakat memerlukan energi listrik. Masyarakat dapat dikatakan kurang peduli terhadap lingkungan, khususnya energi. Perilaku boros energi yang dilakukan pada kelompok ini adalah tidak mematikan AC atau kipas angin, menghidupkan rice-cooker, tidak mematikan komputer atau laptop, menggunakan internet 24 jam. Kepedulian terhadap lingkungan juga dapat ditanamkan melalui pendidikan lingkungan hidup. Penulis ingin membantu memberikan solusi dengan membuat inovasi sebuah game edukasi mengenai penggunaan listrik secara bijak dengan judul "ElectriQuest" yang diharapkan akan mengedukasi anak sekolah dasar dalam penggunaan listrik secara bijak dan menghidupkan sikap hemat energi sejak dini.

Electrical energy is one of the most important basic needs in human life today, because almost every activity carried out by society requires electrical energy. People can be said to care less about the environment, especially energy. Energy wasteful behavior carried out in this group is not turning off the air conditioner or fan, turning on the rice-cooker, not turning off the computer or laptop, using the 24-hour internet. Concern for the environment can also be instilled through environmental education. The author wants to help provide a solution by making an innovative game educational about using electricity wisely with the title "ElectriQuest" which is expected to educate elementary school children in using electricity wisely and turn on energy saving attitudes from an early age.

\section{PENDAHULUAN}

Energi Listrik merupakan salah satu kebutuhan pokok yang sangat penting dalam keidupan manusia saat ini, karena hampir setiap kegiatan yang dilakukan masyarakat memerlukan energi listrik. Kebutuhan energi listrik di Indonesia semakin meningkat. Berdasarkan data dari Kementerian Energi dan Sumber Daya Manusia bahwa konsumsi listrik nasional mengalami peningkatan menjadi $1.084 \mathrm{KWh} /$ kapita pada tahun 2019. (Katadata, 2020). Kementerian Energi dan Sumber Daya Manusia juga memproyeksikan rata-rata kebutuhan energi listrik nasional sebesar 6,9 persen per tahun (Bisnis.com, 2019). Oleh sebab itu, dengan konsumsi yang terus meningkat, Indonesia akan mengalami krisis energi listrik. Menurut data yang diperoleh dari buku statistik energi Indonesia 2017, kapasitas terpasang pembangkit tenaga listrik di Indonesia pada tahun 2017 mencapai
60.789,98 MW yang terdiri dari pembangkit PLN sebesar 41.720,96 MW dan non PLN sebesar 19.069,02 MW. Data distribusi penjualan listrik menunjukkan bahwa persentase energi listrik dikonsumsi oleh sektor rumah tangga yakni sebesar 93.634,63 GWh atau sekitar 49,26\% dari total penjualan listrik. Banyaknya penjualan energi listrik di sektor rumah tangga ini menunjukan bahwa sektor rumah tangga merupakan sektor yang paling banyak mengkonsumsi energi listrik hampir 50\% dari kebutuhan listrik nasional.

Data rata-rata konsumsi energi listrik rumah tangga selama 24 jam. Data survei menunjukkan bahwa 2 perangkat listrik yang mengkonsumsi listrik terbesar dalam rumah tangga adalah pemakaian kulkas, dan AC dengan konsumsi listrik sebesar 2.400 - 2.880 watt/hari. Perangkat listrik dengan konsumsi listrik yang terbesar lainnya yaitu penggunaan rice cooker, lampu dan komputer. (Santoso \& Salim, 2019) 
Kepedulian terhadap lingkungan juga dapat ditanamkan melalui pendidikan lingkungan hidup. Menurut Ratna Widyaningrum (2016, p. 108) pendidikan memiliki peran dalam pembentukan kemampuan, kepribadian, dan karakter sesorang. Pembentukan karakter, sebaiknya dimulai sejak dini agar terbentuk sumber daya manusia yang berkarakter kuat, cerdas, berbudi luhur dan berkepribadian yang baik. Sekolah Dasar merupakan lembaga pendidikan sekolah yang memiliki murid kisaran berusia 7 sampai 13 tahun. Di masa ini anak cenderung memiliki sikap rasa ingin tahu yang kuat sehingga tentu membutuhkan seorang pembimbing. Menurut kementerian lingkungan hidup (2013, p. 85) terdapat beberapa indikator kepedulian terhadap lingkungan yaitu perilaku penghematan energi, membuang sampah, pemanfaatan air, penyumbang emisi karbon, dan perilaku hidup sehat.

Game edukasi dapat mempengaruhi perkembangan motorik, perkembangan fisik, perkembangan neuorologi, perkembangan kognitif, perkembangan moral, perkembangan bahasa, perkembangan sosial, dan perkembangan peran. Tak hanya itu, game juga dapat membuat pemain melakukan interaksi dan pengambilan keputusan dengan mempertimbangkan berbagai kondisi (Henry, 2010).

Dengan latar belakang dan masalah tersebut, penulis ingin membantu memberikan solusi dengan membuat inovasi sebuah game edukasi mengenai penggunaan listrik secara bijak dengan judul "ElectriQuest" yang diharapkan akan mengedukasi anak sekolah dasar dalam penggunaan listrik secara bijak dan menghidupkan sikap hemat energi sejak dini.

\section{LANDASAN TEORI}

\subsection{Game Edukasi}

Game berasal dari bahasa inggris yang berarti permainan. Dalam setiap game terdapat peraturan yang berbeda beda untuk memulai permainannya sehingga membuat jenis game semakin bervariasi. Karena salah satu fungsi game sebagai penghilang stress atau rasa jenuh maka hampir setiap orang senang bermain game baik anak kecil, remaja maupun dewasa, mungkin hanya berbeda dari jenis game yang dimainkannya saja (Mokhammad Ridoi, 2018).

Game sebagai media pembelajaran bukanlah sebuah konsep baru, konsep ini muncul seiring dengan munculnya berbagai macam game (permainan), baik itu game tradisional maupun game digital. Akibatnya secara spesifik muncul istilah game edukasi, yaitu game yang secara khusus memiliki muatan pembelajaran dan ditujukan untuk meningkatkan kemampuan pemainnya dalam mempelajari suatu materi. Game mampu memancing minat belajar pemainnya, sehingga menghasilkan pengalaman baru seperti perasaan senang yang pada akhirnya materi yang ingin disampaikan dapat diterima dengan mudah oleh pemain game (Wibawanto, 2020).

Game edukasi mulai digunakan sebagai peluang untuk dijadikan sebagai media menyampaikan pengetahuan dan pembelajaran, dimana pemain bisa mendapatkan ilmu dengan cara yang menyenangkan. Game edukasi merupakan sebuah permainan yang dibuat dan dirancang khusus untuk dijadikan sebuah media yang digunakan untuk mengajar orang melalui materi yang berisikan suara, teks, gambar, video, dan animasi, yang pokok materinya membahas suatu subjek tertentu, yang memiliki tujuan untuk dapat memperluas konsep, memberikan pemahaman yang lebih baik dari materi yang mengajarkan sebuah peristiwa sejarah maupun budaya, dan dapat pula mengajarkan pengguna dari game edukasi ini dengan baik, karena mereka dapat bermain sambil belajar dengan mudah (Wijaya, 2017).

\subsection{Flowchart}

Flowchart adalah sekumpulan gambargambar tertentu untuk menyatakan alur dari suatu program yang akan diterjemahkan ke salah satu bahasa pemrograman. Kegunaan flowchart yaitu untuk menuliskan alur program tetapi dalam bentuk gambar atau simbol (Setiawan, 2009). Flowchart dibagi menjadi dua bagian, yakni flowchart yang menggambarkan alur suatu sistem dan flowchart yang menggambarkan alur dari suatu program detail. Di dalam praktiknya flowchart ini digunakan untuk membuat suatu program Flowchart dibagi menjadi dua bagian, yakni flowchart yang menggambarkan alur suatu sistem dan flowchart yang menggambarkan alur dari suatu program detail. Di dalam praktiknya flowchart ini digunakan untuk membuat suatu program menjadi sempurna. misalnya, bagi anak smk untuk ujian akhir atau mahasiswa jurusan IT di setiap makalahnya. Flowchart dibagi menjadi dua bagian, yakni flowchart yang menggambarkan alur suatu sistem dan flowchart yang menggambarkan alur dari suatu program detail. Di dalam praktiknya flowchart ini digunakan untuk membuat suatu program menjadi sempurna. misalnya, bagi anak smk untuk ujian akhir atau mahasiswa jurusan IT di setiap makalahnya.

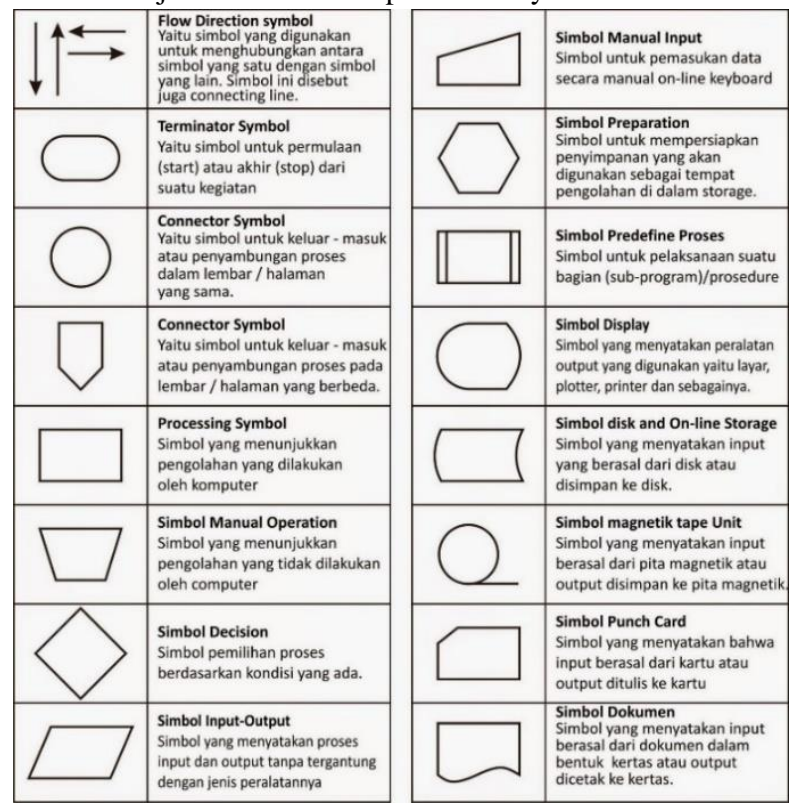

Gambar 2. 1 Simbol Flowchart

Sumber : informatikalogi, 2017 


\subsection{Hemat Listrik}

Hemat energi atau konveksi energi adalah tindakan individu mengurangi jumlah penggunaan energi. Hemat energi dapat dilakukan dengan cara memahami dan memperhitungkan kebutuhan energi yang dibutuhkan, jumlah energi yang digunakan dipengaruhi oleh beberapa faktor diantaranya adalah jenis peralatan yang digunakan, lama waktu pengunaan dan rutinitas penggunaan. Salah satu cara untuk menghemat atau mengurangi energi diantaranya mengurangi durasi penggunaan, mengurangi energi yang tidak terlalu diperlukan, menggunakan peralatan yang memiliki watt rendah (untuk listrik) (WWF, 2009).

Dalam rangka mengoptimalkan penggunaan energi, pemerintah telah mengeluarkan kebijakan energi nasional yang meliputi kebijakan penyediaan energi yang optimal dan melaksanakan konservasi, melaksanakan diversifikasi dalam pemanfaatan energi, menetapkan harga energi ke arah harga ke ekonomian, dan pelestarian lingkungan. Kebijakan konservasi energi dimaksudkan untuk mengikatkan penggunaan energi secara efisien dan rasional tanpa mengurangi kuantitas energi yang memang benar- benar diperlukan (BPPT, 2012).

\section{KONSEP PERANCANGAN}

\subsection{Media Pembelajaran yang Akan Dibuat}

Dalam Karya Tugas Akhir ini, penulis membuat game edukasi tentang penggunaan energi listrik secara bijak berbasis Android sehingga dapat game edukasi dapat dimainkan di ponsel pintar pemain.

\subsubsection{Rencana Pembuatan}

Adapun rencana dalam pembuatan game edukasi tentang penggunaan energi listrik secara bijak berbasis Android melalui tiga tahap, yaitu tahap pra produksi yang dilaksanakan sebelum pembuatan karya, tahap produksi adalah memulai pembuatan karya dan tahap pasca produksi yaitu pengujian setelah karya selesai dibuat. Gambaran alur kerja dalam pembuatan karya ini ditunjukkan pada gambar 3.1 :

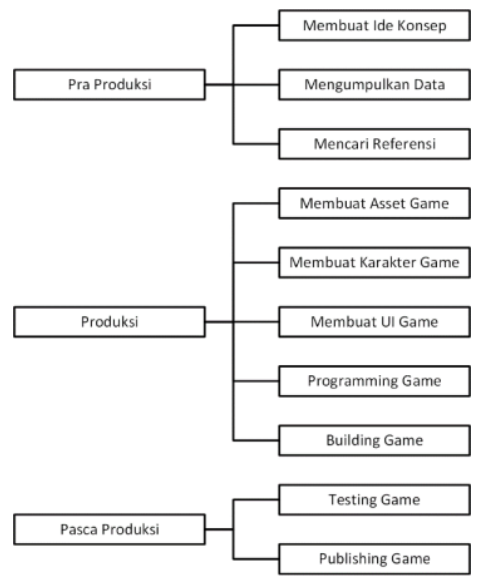

Gambar 3. 1 Gambar Alur Proses Kerja

Sumber: Data Pribadi

\subsubsection{Proses}

\subsubsection{Tahap Pra Produksi}

Pada tahap pra produksi terdapat 3 langkah yang akan dilakukan. Pertama adalah ide dan konsep, dalam tahap ini penulis mendapatkan ide dan konsep serta mengumpulkan data melalui metode studi pustaka dari buku, jurnal, website dan internet mengenai permasalahan konsumsi energi listrik yang masih tinggi dan kelalaian penggunaan energi listrik. Penulis mencari referensi setelah data telah terkumpul dan menjadikannya sebagai referensi dan bahan tugas akhir untuk patokan pembuatan Karya Tugas Akhir yang akan dikerjakan. Beberapa judul referensi yang penulis jadikan acuan diantarnya yaitu "Pembuatan Game Edukasi Menyusun Ayat Alquran Berbasis Android” oleh Romeizatul Huwaida dari Karya Tugas Akhir tahun 2019. Lalu dari Karya Tugas Akhir itulah penulis menuangkan ide konsep kedalam bentuk sketsa untuk tampilan user interface, dan juga asset yang digunakan ke dalam game.

\subsubsection{Tahap Produksi}

Setelah tahap pra produksi selesai, selanjutnya penulis masuk ke dalam tahap produksi. Tahap produksi yaitu tahap dimana proses ini bisa dibilang sebagai tahap utama. Dalam tahap produksi, semua ide konsep perlu dituangkan kedalam bentuk karya game atau permainan yang sudah di rencanakan. Adapun tahapan yang penulis susun adalah sebagai berikut:

\section{Membuat Asset Game}

Pada tahap ini, penulis membuat asset game berupa background game, tileset. Pembuatan illustrasi ini menggunakan software Adobe Illustrator CC 2017.

\section{Membuat Karakter Game}

Selanjutnya, penulis membuat karakter game karena game yang di buat penulis memiliki jalan cerita yang terdapat karakter yang dapat dimainkan. Pembuatan illustrasi ini menggunakan software Adobe Illustrator CC 2017.

\section{Membuat User Interface Game}

Lalu disini penulis juga masuk ke tahap pembuatan User Interface (UI) aplikasi atau disebut juga tampilan antarmuka pengguna. User Interface berfungsi untuk menghubungkan antara pengguna dengan sistem operasi, sehingga komputer atau sistem tersebut bisa digunakan. Software yang penulis pakai untuk pembuatan user interface ini adalah Adobe XD dan Adobe Illustrator CC 2017.

4. Programming Game

Tahap programming merupakan tahap dimana penulis memberikan bahasa pemrograman pada game sesuai fungsi dari script yang ingin dibuat. Bahasa pemrograman yang dibuat untuk pembuatan game ini biasa disebut C\# atau C Sharp. Software yang penulis pakai untuk membuat dan mengedit script C\# ini yaitu Visual Studio Code 2019.

\section{Building Game}

Setelah semua tahapan pembuatan aplikasi selesai, maka bisa langsung masuk ke tahap building aplikasi ke bentuk format APK. Software untuk melakukan build itu sendiri tetap menggunakan Unity 3D, hanya saja dengan support dari tools SDK dan JDK yang perlu di-install terlebih dahulu dan dihubungkan ke software Unity 3D dengan cara setting pada bagian menu preferences $\square$ external tools. 


\subsubsection{Tahap Pasca Produksi}

Setelah semua proses pengerjaan dari tahap produksi selesai, lalu tahap selanjutnya untuk penulis adalah melakukan uji coba terhadap aplikasi yang telah dibuat untuk memastikan apakah aplikasi sudah berjalan sesuai fungsinya atau masih ada beberapa bug lainnya. Apabila masih terdapat bug, penulis akan segera memperbaikinya kembali hingga aplikasi siap dipublikasikan dan digunakan.

\subsection{Perancangan Sistem}

Perancangan sistem dalam pembuatan Karya Tugas Akhir ini menggunakan Flowchart yang di gunakan untuk memperjelas alur kerja dari game yang dibuat. Flowchart adalah penggambaran secara grafik dari langkah-langkah dan uruturutan prosedur dari suatu program. Flowchart sendiri digunakan untuk menolong analis dan programmer untuk memecahkan masalah kedalam segmen-segmen yang lebih kecil dan menolong dalam menganalisis alternatif-alternatif lain dalam pengoperasian. Flowchart biasanya mempermudah penyelesaian suatu masalah khususnya masalah yang perlu dipelajari dan dievaluasi lebih lanjut. Berikut ini beberapa flowchart yang ditampilkan

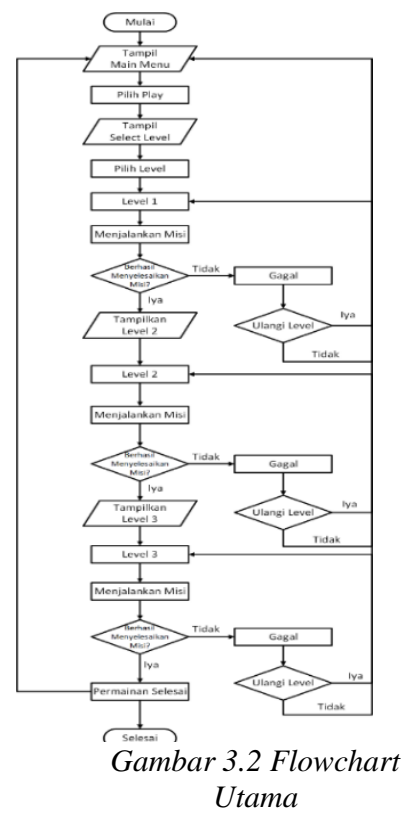

Sumber : Data Penulis

Pada gambar di atas merupakan flowchart utama yang menjelaskan alur kerja/langkah kerja yang dilakukan oleh sistem pada game. Seperti memulai permainan, masuk ke halaman menu lalu memilih memulai permainan, lalu akan ditampilkan halaman pilih level, pemain dapat memilih level 1 jika baru memulai permainan, atau jika sudah menyelesaikan permainan pemain dapat memilih level lainnya. Pemain diberikan misi/quest di setiap levelnya. Jika berhasil, pemain dapat melanjutkan ke level berikutnya, jika gagal pemain dapat mengulangi permainan di level tersebut.

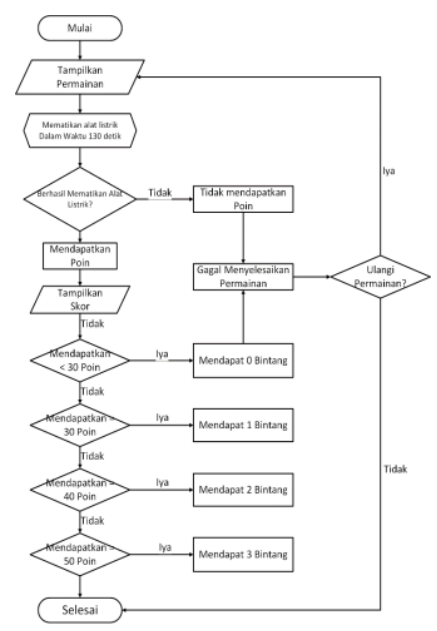

Gambar 3.4 Flowchart Score Level 1

Sumber : Data Penulis

Pada gambar diatas merupakan flowchart yang digunakan untuk menampilkan alur bagaimana pemain mendapatkan score atau nilai di level 1 . Dimulai dari pemain memulai permainan lalu pemain diberi waktu 130 detik untuk mematikan alat elektronik atau alat listrik sebanyak 5 alat elektronik atau alat listrik. Jika berhasil, pemain dapat melanjutkan ke level berikutnya dan mendapatkan bintang. Jika gagal, pemain tidak dapat melanjutkan ke level berikutnya dan harus mengulangi dilevel 1 dan tidak dapat bintang.

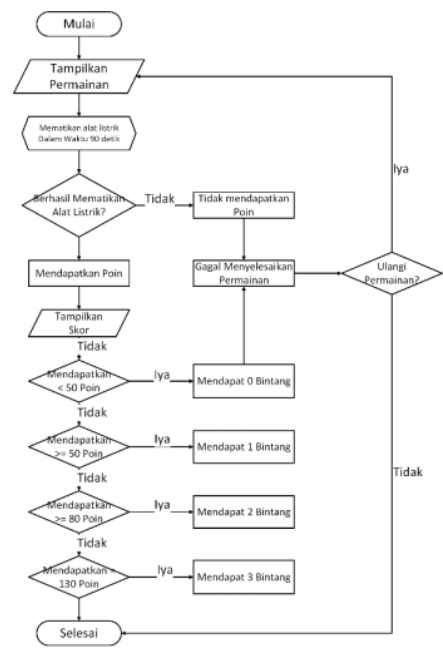

Gambar 3.3 Flowchart Score Level 2

Sumber : Data Penulis 
Pada gambar diatas merupakan flowchart yang digunakan untuk menampilkan alur bagaimana pemain mendapatkan score atau nilai di level 2. Dimulai dari pemain memulai permainan lalu pemain diberi waktu 165 detik untuk mematikan alat elektronik atau alat listrik sebanyak 13 alat elektronik atau alat listrik. Jika berhasil, pemain dapat melanjutkan ke level berikutnya dan mendapatkan bintang. Jika gagal, pemain tidak dapat melanjutkan ke level berikutnya dan harus mengulangi dilevel 2 dan tidak dapat bintang.

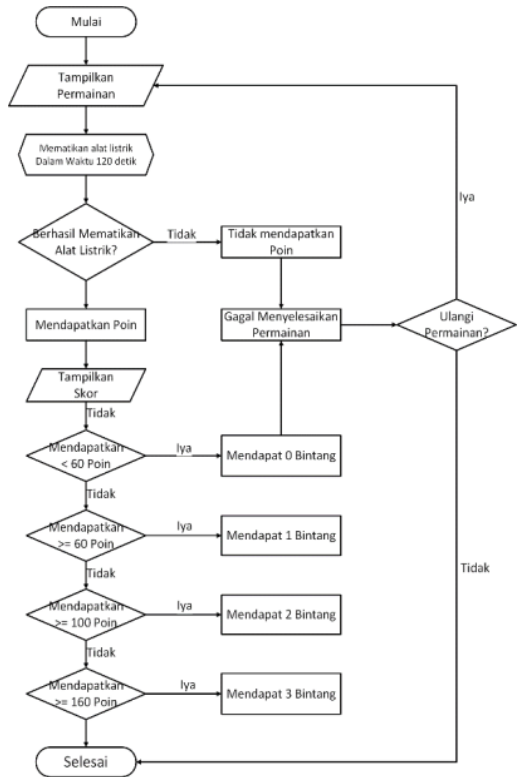

Gambar 3.5 Flowchart Score Level 3

Sumber : Data Penulis

Pada gambar diatas merupakan flowchart yang digunakan untuk menampilkan alur bagaimana pemain mendapatkan score atau nilai di level 3. Dimulai dari pemain memulai permainan lalu pemain diberi waktu 180 detik untuk mematikan alat elektronik atau alat listrik sebanyak 16 alat elektronik atau alat listrik. Jika berhasil, pemain dapat melanjutkan ke level berikutnya dan mendapatkan bintang. Jika gagal, pemain tidak dapat melanjutkan ke level berikutnya dan harus mengulangi dilevel 3 dan tidak dapat bintang.

\subsubsection{Analisis Scoring}

Aplikasi Game ElectriQuest memiliki score yang diterapkan disetiap masing-masing levelnya. Pemain akan mendapatkan score jika berhasil menjalankan misi atau mematikan alat elektronik yang berada diruangan. Dalam game ini terdapat score minimal dan score maksimal untuk lanjut ke level berikutnya. Penetapan point minimal diambil dari perkiraan jumlah soal disetiap levelnya. Untuk akumulasi point sebagai berikut:

1. Level 1 : Hanya terdapat 5 lampu yang menyala diruangan. Alat Elektronik yang dimatikan minimal 3 dan maksimal 5. Jika semua sudah dimatikan 50 point.

2. Level 2 : Terdapat 11 lampu yang menyala diruangan, 1 televisi dan 1 Pintu kulkas yang terbuka. Alat elektronik minimal 5 dan maksimal 13. Jika semua sudah dimatikan 130 point.

3. Level 3 : Terdapat 12 lampu yang menyala diruangan, 1 televisi, 1 Pintu kulkas yang terbuka, 2 komputer yang menyala.
Alat elektronik minimal 6 dan maksimal 16. Jika semua sudah dimatikan 160 point.

\subsection{Perancangan Antar Muka Pengguna (User Interface)}

\subsubsection{Struktur Menu}

Dalam perancangan Karya Tugas Akhir, penulis membuat rancangan antar menu guna memudahkan pengurutan menu ketika nanti sudah masuk ke tahap pembuatan user interface untuk game edukasi tentang penggunaan energi listrik secara bijak berbasis Android. Berikut adalah gambaran struktur menu yang penulis buat dalam bentuk sitemap:

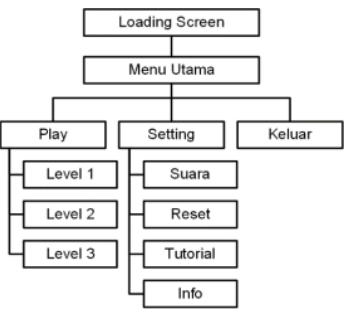

Gambar 3.7 Struktur Menu

Sumber : Data Penulis

\subsubsection{Rancangan Tampilan Halaman Loading}

Halaman loading merupakan tampilan berikutnya setelah halaman splash screen muncul. Pada halaman loading terdapat loading bar berbentuk persegi panjang bersudut tumpul dengan warna gelap dengan posisi horizontal yang lama-kelamaan akan terisi penuh, dan menandakan akan segera masuk ke menu utama. Berikut layout loading yang penulis rancang:

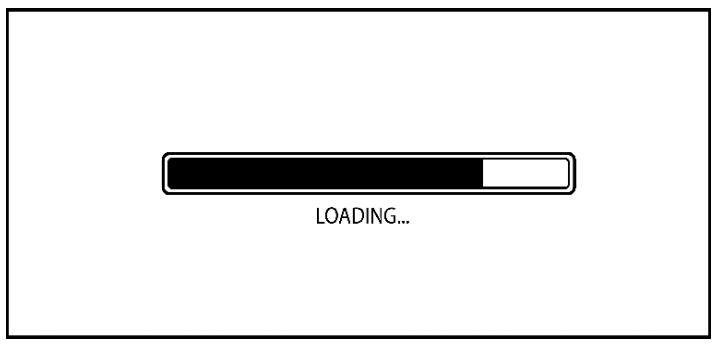

Gambar 3.6 Rancangan Tampilan Halaman Loading Sumber : Data Penulis

\subsubsection{Rancangan Tampilan Halaman Menu Utama}

Halaman menu utama merupakan tampilan ketika sudah melewati halaman loading dan terdapat kumpulan button yang mempunyai fungsinya masingmasing. Pada rancangan menu yang penulis buat terdapat logo permainan, button play, setting, informasi, petunjuk permainan, dan keluar dari permainan. Berikut layout main menu yang penulis rancang:

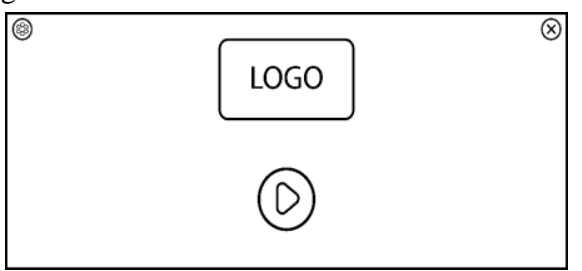


Gambar 3.8 Rancangan Tampilan Halaman Menu Utama Sumber : Data Penulis

\subsubsection{Rancangan Tampilan Halaman Pilih Level}

Halaman pilih level merupakan tampilan ketika akan memulai permainan, pemain diharuskan memilih level yang akan dimainkan. Halaman ini memiliki enam Button yaitu lima button untuk memilih level, 1 button back untuk kembali ke halaman utama. Berikut layout select level yang penulis rancang:

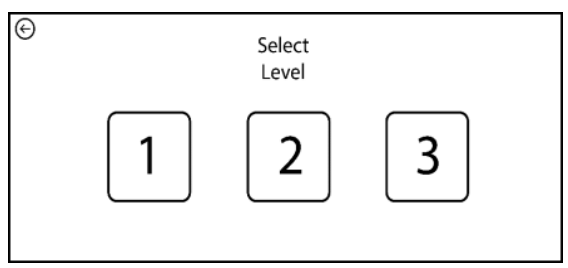

Gambar 3.9 Rancangan Tampilan Halaman Pilih Level

Sumber : Data Penulis

\subsubsection{Rancangan Tampilan Permainan}

Tampilan Permainan merupakan tampilan utama dari permainan. Tampilan ini memiliki 3 level. Berikut layout permainan yang penulis rancang:

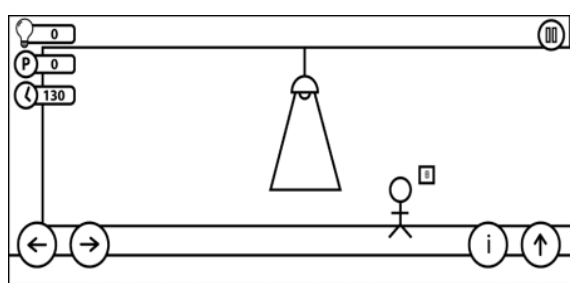

Gambar 3.10 Rancangan Tampilan Permainan Level 1 Sumber : Data Penulis

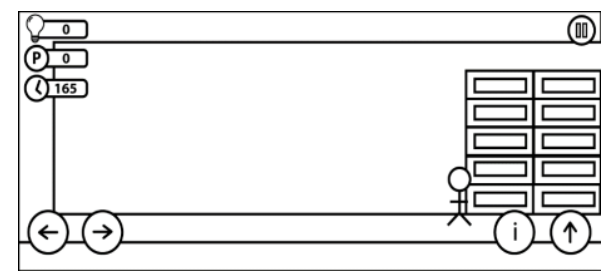

Gambar 3.12 Rancangan Tampilan Permainan Level 2

Sumber : Data Penulis

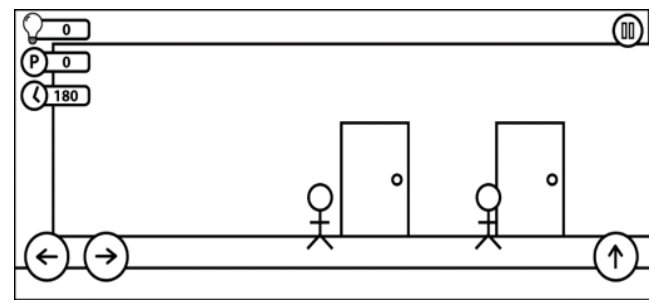

Gambar 3.11 Rancangan Tampilan Permainan Level 3

Sumber : Data Penulis

\subsubsection{Rancangan Tampilan Pause}

Tampilan pause merupakan tampilan dimana saat pemain ingin menghentikan sejenak permainan, agar sistem yang ada dipermainan tidak berjalan saat game tidak dimainkan oleh pemain. Berikut layout pause yang penulis rancang.

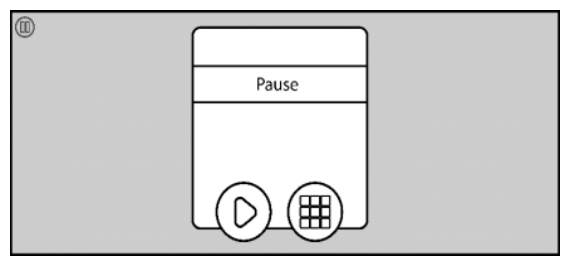

Gambar 3.13 Rancangan Tampilan Pause

Sumber : Data Penulis

\subsubsection{Rancangan Tampilan Berhasil} Menyelesaikan Level

Tampilan berhasil menyelesaikan level merupakan tampilan dimana saat pemain dapat menyelesaikan misi dalam permainan. Berikut layout menyelesaikan level yang penulis rancang:

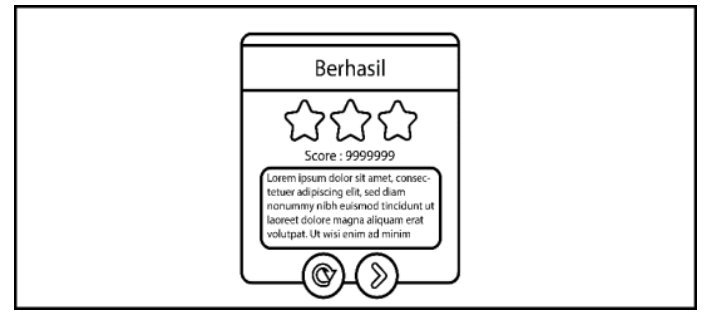

Gambar 3.14 Rancangan Tampilan Menyelesaikan Level Sumber : Data Penulis

\subsubsection{Rancangan Tampilan Gagal}

Menyelesaikan Level

Tampilan gagal menyelesaikan level merupakan tampilan dimana saat pemain tidak dapat menyelesaikan misi dalam permainan. Berikut layout gagal menyelesaikan level yang penulis rancang:

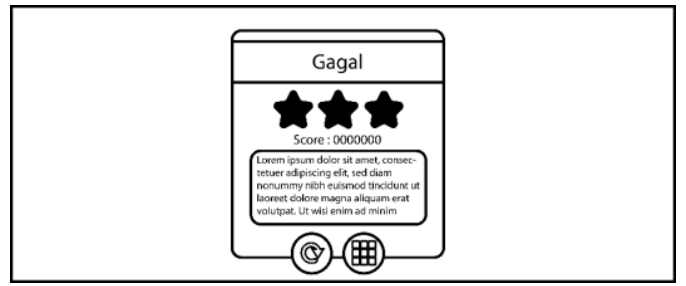

Gambar 3.15 Rancangan Tampilan Gagal Menyelesaikan Level Sumber : Data Penulis

\subsubsection{Rancangan Tampilan Popup Tutorial}

Popup tutorial merupakan tampilan popup yang berisi tentang petunjuk permainan agar pemain dapat memahami cara bermain permainan ini. Berikut Popup tutorial yang penulis rancang: 


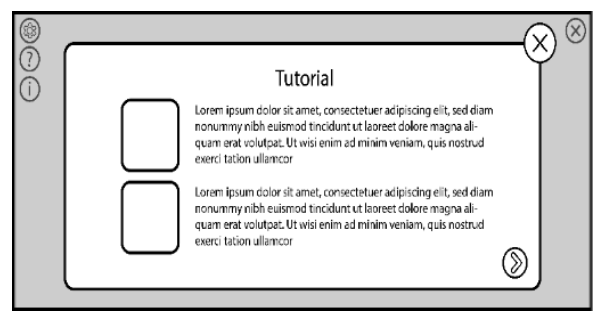

Gambar 3.16 Rancangan Tampilan Popup Tutorial Sumber : Data Penulis

\subsubsection{Rancangan Tampilan Popup Info}

Popup info merupakan tampilan popup yang berisi info tentang permainan ini. Berikut popup info yang penulis rancang:

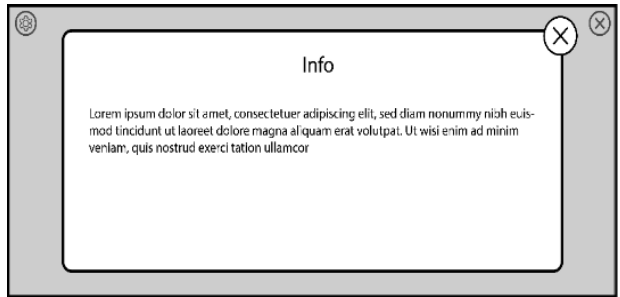

Gambar 3.18 Rancangan Tampilan Popup Info

Sumber : Data Penulis

\subsubsection{Rancangan Tampilan Popup Reset}

Popup reset merupakan tampilan popup dialog ketika pemain ingin mengulangi progress permainan yang telah dimainkan. Pemain akan ditanyakan apakah ingin mengulang permainan atau tidak. Jika memilih iya, maka pemain akan mengulangi permainan dari level 1 lalu jika memilih tidak, maka pemain akan level 2 dan level 3 akan tetap terbuka dan bisa diakses. Berikut popup Close yang penulis rancang:

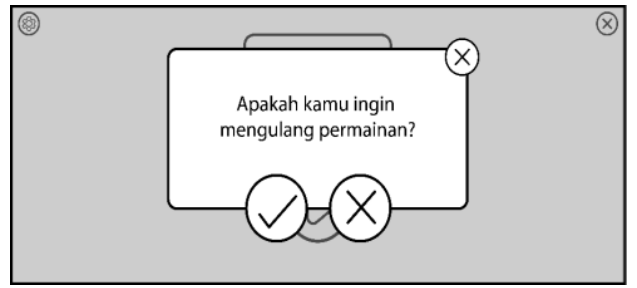

Gambar 3.19 Rancangan Tampilan Popup Reset

Sumber : Data Penulis

\subsubsection{Rancangan Tampilan Popup Close}

Popup close merupakan tampilan popup dialog ketika akan menutup aplikasi permainan, pemain akan ditanyakan apakah ingin keluar dari permainan atau tetap melanjutkan permainan. Jika memilih iya, maka pemain akan keluar dan menutup aplikasi permainan dari permainan lalu jika memilih tidak, maka pemain akan tetap dipermainan. Berikut popup Close yang penulis rancang:

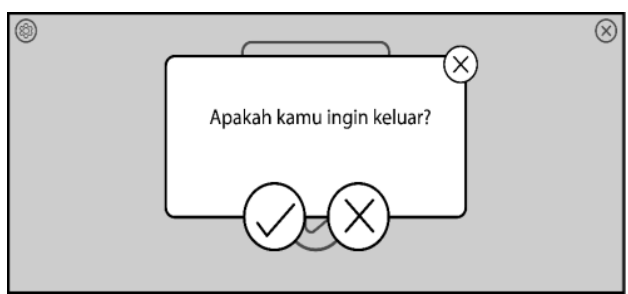

Gambar 3.17 Rancangan Tampilan Popup Close

Sumber : Data Penulis

\section{HASIL DAN PEMBAHASAN}

\subsection{Implementasi Sistem}

Pada poin ini penulis akan menjabarkan hasil implementasi setelah dibuat kedalam bentuk karya.

\subsubsection{Tampilan Halaman Loading}

Berikut hasil impelentasi halaman loading screen dari sebuah rancangan yang dibuat sebelumnya:

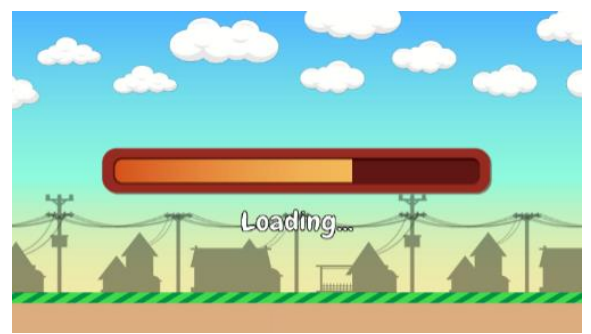

Gambar 4.1 Implementasi Halaman Loading Screen Sumber : Data Penulis

\subsubsection{Tampilan Halaman Main Menu}

Berikut hasil impelentasi halaman menu utama dari sebuah rancangan yang dibuat sebelumnya:

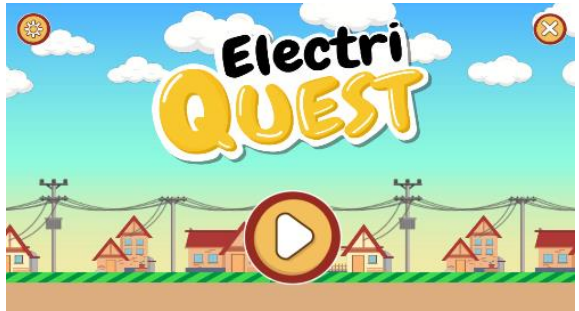

Gambar 4.2 Implementasi Halaman Menu Utama Sumber : Data Penulis

\subsubsection{Tampilan Halaman Pilih Level}

Berikut hasil impelentasi halaman pilih level dari sebuah rancangan yang dibuat sebelumnya:

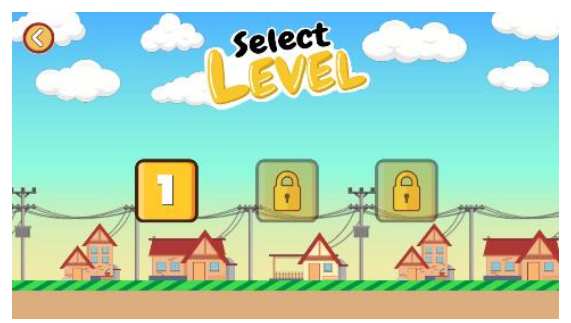


Gambar 4.3 Implementasi Halaman Pilih Level Sumber : Data Penulis

\subsubsection{Tampilan Permainan}

Berikut hasil impelentasi tampilan permainan dari sebuah rancangan yang dibuat sebelumnya:

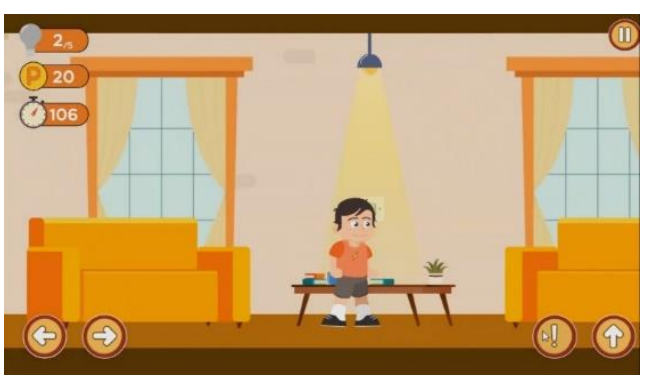

Gambar 4.4 Implementasi Tampilan Permainan Level 1

umber : Data Penulis

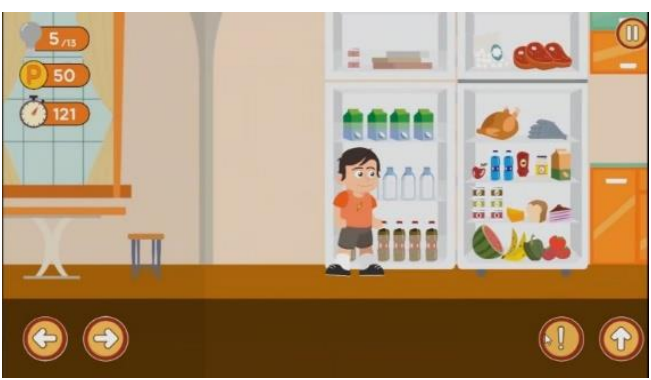

Gambar 4.5 Implementasi Tampilan Permainan Level 2

Sumber : Data Penulis

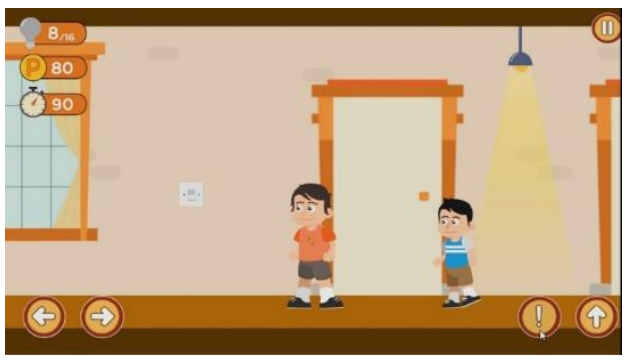

Gambar 4.7 Implementasi Tampilan Permainan Level 3

Sumber : Data Penulis

\subsubsection{Tampilan Pause}

Berikut hasil impelentasi popup pause dari sebuah rancangan yang dibuat sebelumnya:

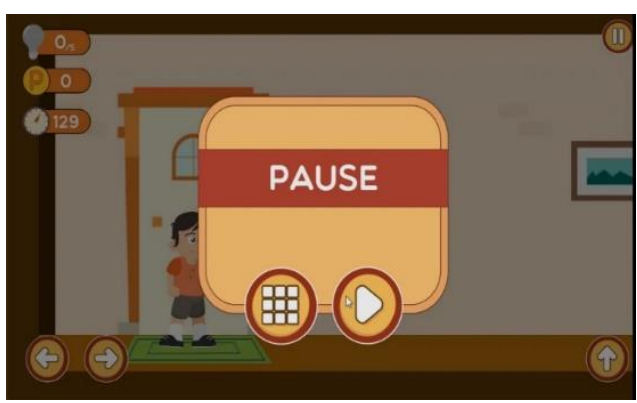

Gambar 4.8 Implementasi Tampilan Popup Pause Sumber : Data Penulis

\subsubsection{Tampilan Menyelesaikan Level}

Berikut hasil impelentasi popup menyelesaikan level dari sebuah rancangan yang dibuat sebelumny

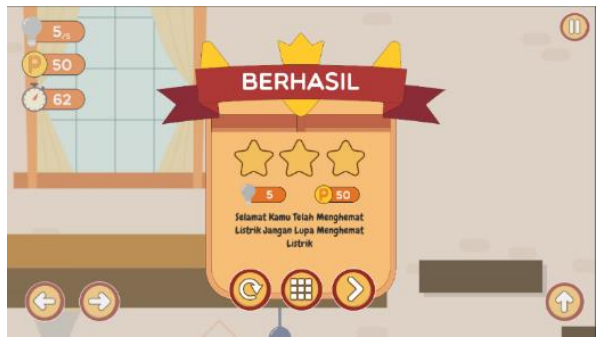

Gambar 4.9 Implementasi Tampilan Popup

Menyelesaikan Level

Sumber : Data Penulis

\subsubsection{Tampilan Gagal Menyelesaikan Level}

Berikut hasil impelentasi popup gagal menyelesaikan level dari sebuah rancangan yang dibuat sebelumnya:

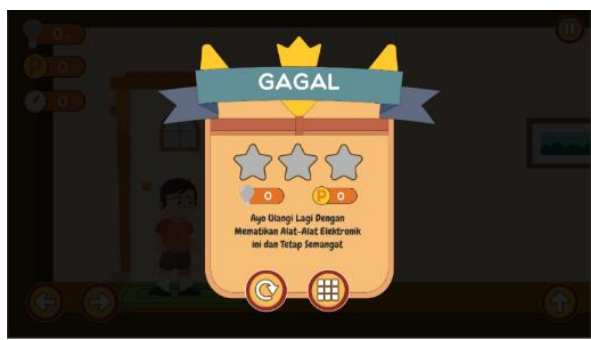

Gambar 4.6 Implementasi Tampilan Popup Gagal Menyelesaikan Level Sumber : Data Penulis

\subsubsection{Tampilan Tampilan Popup Tutorial}

Berikut hasil impelentasi popup tutorial dari sebuah rancangan yang dibuat sebelumnya: 


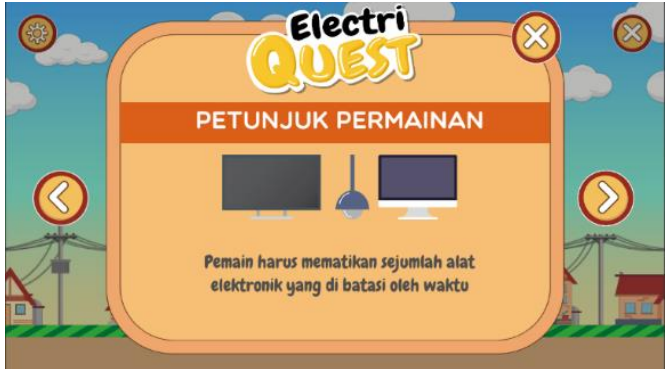

Gambar 4.11 Implementasi Tampilan Popup

Tutorial

Sumber : Data Penulis

4.1.9. Tampilan Tampilan Popup Info

Berikut hasil impelentasi popup info dari sebuah rancangan yang dibuat sebelumnya:

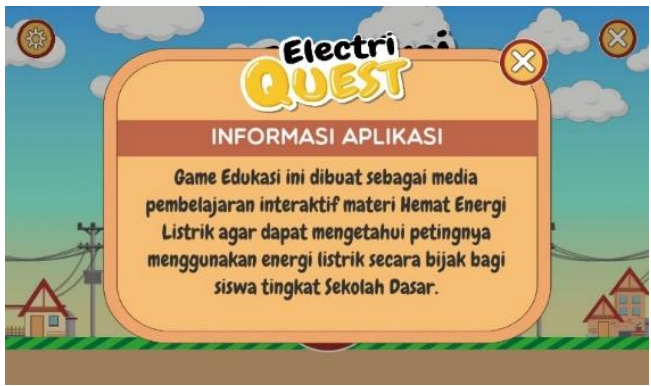

Gambar 4.12 Implementasi Tampilan Popup Info

Sumber : Data Penulis

\subsubsection{Tampilan Tampilan Popup Reset}

Berikut hasil impelentasi popup reset dari sebuah rancangan yang dibuat sebelumnya:

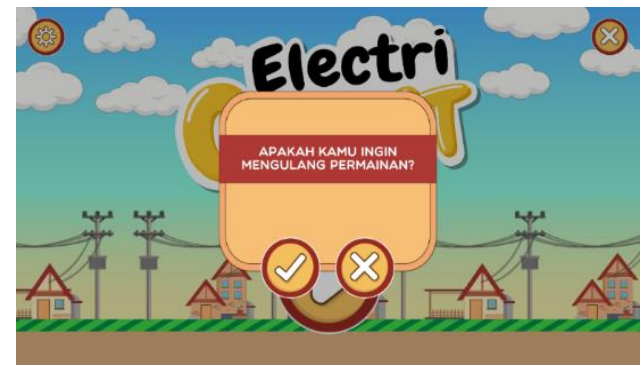

Gambar 4.13 Implementasi Tampilan Popup Reset

Sumber : Data Penulis

\subsubsection{Tampilan Tampilan Popup Close}

Berikut hasil impelentasi popup close dari sebuah rancangan yang dibuat sebelumnya:

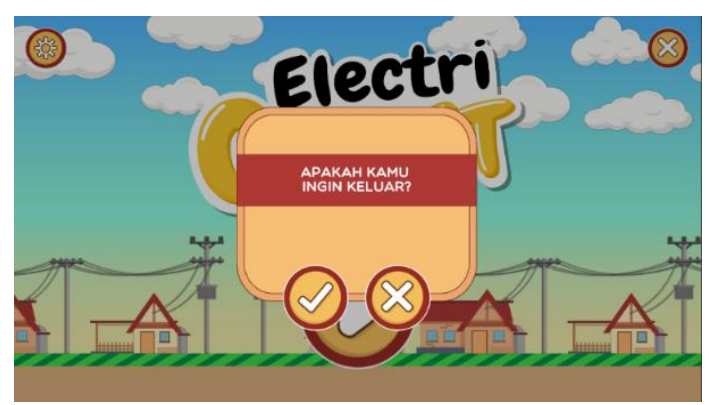

Gambar 4.10 Implementasi Tampilan Popup Close Sumber : Data Penulis

\subsection{Kebutuhan Pemakai Sistem}

Pemakaian sistem yang dibutuhkan dalam pembuatan game edukasi penggunaan energi listrik secara bijak adalah sebagai berikut :

\section{Asset-asset game}

Asset-asset atau sprite yang dibutuhkan dalam tampilan antarmuka (user interface) dalam game edukasi penggunaan energi listrik secara bijak berupa background, button, logo, teks, dan objek pelengkap lainnya.

a) Aplikasi yang digunakan : Adobe Illustrator

b) Ukuran yang digunakan :

Tabel 4.1 Asset User Interface

\begin{tabular}{|l|l|}
\hline \multicolumn{1}{|c|}{ Asset } & \multicolumn{1}{|c|}{ Ukuran } \\
\hline Background & $\begin{array}{l}12334 \\
6001 \mathrm{px}\end{array}$ \\
\hline Icon & 96 x 96 px \\
\hline Logo & $\begin{array}{l}5243 \times 3320 \\
\mathrm{px}\end{array}$ \\
\hline Button & $389 \times 388 \mathrm{px}$ \\
\hline Pop Up & $1736 \times 2088$ \\
$\mathrm{px}$
\end{tabular}

\section{Audio}

Audio yang digunakan dalam game ini berupa backsound, sound effect, dan audio rekaman untuk kebutuhan petunjuk soal. Format yang digunakan adalah .mp3, .wav dan .ogg.

Tabel 4.2 Aset Audio Backsound

\begin{tabular}{|c|c|c|}
\hline \multicolumn{3}{|c|}{ Backsound } \\
\hline Judul & Sumber & $\begin{array}{c}\text { Ukura } \\
\mathrm{n}\end{array}$ \\
\hline
\end{tabular}




\begin{tabular}{|c|c|c|}
\hline Fretless & $\begin{array}{c}\text { incomptech.filmmusic.i } \\
\text { o }\end{array}$ & $\begin{array}{c}10.76 \\
\text { MB }\end{array}$ \\
\hline Cheeky & & 817 \\
Monke & www.zapsplat.com & KB \\
y & & \\
\hline
\end{tabular}

Tabel 4.3 Aset Audio Sound Effect

\begin{tabular}{|c|c|c|}
\hline \multicolumn{3}{|c|}{ Sound effect } \\
\hline Judul & Sumber & $\begin{array}{c}\text { Ukura } \\
\mathrm{n}\end{array}$ \\
\hline $\begin{array}{l}\text { Multimedi } \\
\text { a Button } \\
\text { Click } 29\end{array}$ & www.zapsplat.com & $\begin{array}{l}3.34 \\
\mathrm{~KB}\end{array}$ \\
\hline $\begin{array}{l}\text { Multimedi } \\
\text { a Button } \\
\text { Click 1 }\end{array}$ & www.zapsplat.com & $\begin{array}{l}3.34 \\
\text { KB }\end{array}$ \\
\hline Jump_01 & $\begin{array}{l}\text { www.opengameart.or } \\
\text { g/ } \\
\text { content/platformer- } \\
\text { jumping-sounds }\end{array}$ & $\begin{array}{l}15.6 \\
\mathrm{~KB}\end{array}$ \\
\hline
\end{tabular}

\subsection{Pengujian Sistem}

Tahap ini merupakan tahap uji coba memasang dan menjalankan aplikasi yang sudah dibangun kedalam smartphone Android. Uji coba ini telah dilakukan di empat perangkat smartphone Android dengan versi sistem operasi yang berbeda. Apabila ada masalah pada aplikasi tersebut akan dilakukan perbaikan (trial and error) hingga aplikasi dapat dijalankan dan berfungsi sebagai mestinya. Dari hasil keseluruhan uji coba diatas dapat disimpulkan bahwa aplikasi game "ElectriQuest" dapat berjalan baik di semua perangkat dan tidak terjadi error atau kesalahan tampilan pada aplikasi semua fitur berfungsi sebagaimana mestinya, performa terbaik terdapat pada smartphone Redmi Note 8 Pro.

\section{KESIMPULAN DAN SARAN}

\subsection{Simpulan}

Kesimpulan karya Tugas Akhir yang telah dibuat yaitu "Pembuatan Game Edukasi Tentang Penggunaan Energi Listrik Secara Bijak Berbasis Android" adalah sebagai media penunjang pembelajaran agar siswa dapat mempelajari materi penghematan listrik secara interaktif, sehingga meningkatkan minat dan pemahaman siswa untuk menggunakan energi listrik secara bijak. Pembuatan karya Tugas akhir ini hanya sampai tahap pengembangan tanpa melakukan tahap evaluasi secara langsung kepada siswa Sekolah Dasar, sehingga tidak menutup kemungkinan untuk dapat dikembangkan lagi pada penelitian berikutnya.

\subsection{Saran}

Penulis menyadari bahwa aplikasi ini masih jauh dari kata sempurna, maka dari itu aplikasi ini masih dapat dikembangkan lagi. Beberapa hal yang dapat dikembangkan dari game edukasi tentang penggunaan energi listrik secara bijak berbasis Android ini diantaranya adalah:

1. Game dapat dikembangkan agar pemain dapat memainkan secara multiplayer.

2. Game dapat dikembangkan agar dapat multi bahasa.

3. Level pada game diperbanyak dan dikembangkan lagi.

4. User Interface dibuat lebih interaktif dan lebih menarik lagi.

5. Pemain dapat memilih karakter yang berbeda.

6. Game dapat dikembangkan ke dalam versi sistem operasi lain seperti iOS.

\section{DAFTAR PUSTAKA}

[1]. Bisnis.com. (2019, Oktober 1). ESDM: Kebutuhan Listrik Nasional Naik 6,9 Persen Tiap Tahun. Retrieved from Tempo.Co: https://bisnis.tempo.co/read/1254541/esdmkebutuhan-listrik-nasional-naik-69-persen-tiap-tahun

[2]. BPPT. (2012). Perencanaan Efisiensi dan Elastisitas Energi 2012. Tangerang Selatan: BPPT.

[3]. Henry, S. (2010). Cerdas Dengan Game. Jakarta: PT. Gramedia Pustaka Utama.

[4]. Huwaida, R. (2019). Pembuatan Game Edukasi Menyusun Ayat Al Quran. Jakarta: Politeknik Negeri Media Kreatif Jakarta.

[5]. Katadata. (2020, January 09). Konsumsi Listrik Nasional Terus Meningkat: Katadata. Retrieved from Katadata:

https://databoks.katadata.co.id/datapublish/2020/01/10 /konsumsi-listrik-nasional-terus-meningkat

[6]. Kementerian Lingkungan Hidup. (2013). Perilaku Masyarakat Peduli Lingkungan (Survei KLH). Jakarta: Kementerian Lingkungan Hidup Republik Indonesia.

[7]. Mokhammad Ridoi, S. (2018). Cara Mudah Membuat Game Edukasi Dengan Construct 2. Malang.

[8]. Rahmadyani, H., \& Kusuma, H. E. (2019). EMPAT KELOMPOK PERILAKU BOROS ENERGI: PENYUSUNAN HIPOTESIS MENGGUNAKAN GROUNDED THEORY. 85-87. 
[9]. Santoso, A. D., \& Salim, M. A. (2019). Penghematan Listrik Rumah Tangga dalam Menunjang Kestabilan Energi Nasional dan Kelestarian Lingkungan. 266.

[10]. Setiawan, R. (2009). TEKNIK PEMACAHAN MASALAH DENGAN ALGORITMA DAN FLOWCHART(BASIC DAN C). Jakarta: Lentera Ilmu Cendekia.

[11].Wibawanto, W. (2020). Game Edukasi RPG (Role Playing Game). Semarang: Penerbit LPPM UNNES.

[12].Wibowo, D. C. (2019). Apa itu Android Studio dan Android SDK? Retrieved from Dicoding: https://www.dicoding.com/blog/apa-itu-androidstudio-dan-android-sdk/

[13].Widyaningrum, R. (2016, Februari). Pembentukan Karakter Peduli Lingkungan Siswa Sekolah Dasar Melalui Sekolah Peduli dan Berbudaya Lingkungan. Widya Wacana, 108.

[14].Wijaya, R. F. (2017). Pengertian Edukasi dan Pengertian Game Edukasi. Retrieved from Dunia Teknik Informatika: https://www.rianfartawijaya.com/2015/02/pengertianedukasi-danpengertian-game.html

\section{BIODATA PENULIS}

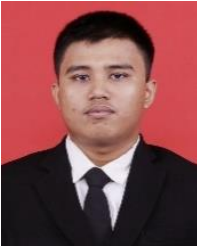

Ruri Wijaya

Lahir pada tanggal 05 Juni 1998 di Bogor. Seorang mahasiswa yang sedang menempuh pendidikan multimedia di Politeknik Negeri Media Kreatif Jakarta. Penulis dapat dihubungi melewati email rury.wijaya@gmail.com 